\title{
OXYGEN ISOTOPIC FRACTIONATION IN RAT BONES AS A RESULT OF CONSUMING THERMALLY PROCESSED WATER - BIOARCHAEOLOGICAL APPLICATIONS
}

\author{
ALEKSANDRA LISOWSKA-GACZOREK ${ }^{1}$, KRZYSZTOF SZOSTEK ${ }^{2}$, JACEK PAWLYTA ${ }^{3}$ \\ and BEATA CIENKOSZ-STEPAŃCZAK ${ }^{4}$ \\ ${ }^{I}$ Department of Environmental Chemistry, Institute of Biological Sciences, Cardinal Wyszyński University in Warsaw, \\ Wóycickiego 1/3, 01-918 Warsaw, Poland \\ ${ }^{2}$ Department of Human Ecology, Institute of Biological Sciences, Cardinal Wyszynski University in Warsaw, \\ Wóycickiego 1/3, 01-918 Warsaw, Poland \\ ${ }^{3}$ Division of Radioisotopes, Institute of Physics Centre for Science and Education, Silesian University of Technology, \\ Konarskiego 22B, 44-100 Gliwice, Poland \\ ${ }^{4}$ Departament of Anthropology, Institute of Zoology and Biomedical Research, Jagiellonian University in Krakow, \\ Gronostajowa 9, 30-387 Krakow, Poland
}

Received 22 July 2019 Accepted 29 October 2019

\begin{abstract}
Stable isotope analyses of oxygen are used in anthropology for such purposes as determination of origin of individuals, tracking migration routes or dynamics of human community relocation. The methodology related to oxygen isotope analysis has been founded on the relationship between its isotopic composition within phosphate groups of bone tissue $\left(\delta^{18} \mathrm{O}_{\mathrm{p}}\right)$ in individuals being analysed and the water consumed by such individuals $\left(\delta^{18} \mathrm{O}_{\mathrm{w}}\right)$. Such a relationship has been observed in many species of mammals, including humans. However, the influence of culinary practices on the isotopic delta values of apatite phosphates of individuals has not yet been researched. The present study, which was conducted using laboratory rats, is an investigation of the influence of the thermal processing of water drank by such rats on the isotopic composition $\left(\delta^{18} \mathrm{O}_{\mathrm{p}}\right)$ of bone apatite. Increasing the value of the isotopic composition of water by about $6.1 \%$ during boiling resulted in an increase in the oxygen isotopic value $\delta^{18} \mathrm{O}_{\mathrm{p}}$ of rats drinking the water by about $4 \%(29 \%)$. It can be expected that regular consumption of heavily isotopic drinks and foods by humans may cause the $\delta^{18} \mathrm{O}_{\mathrm{p}}$ of individuals to exceed the range of isotopic environmental variability, even by a few per mille.
\end{abstract}

Keywords: oxygen isotopes, cooking water, fractionation, bones, teeth, rats.

\section{INTRODUCTION}

The analysis of stable oxygen isotope ratios $\left(\delta^{18} \mathrm{O}\right)$ is a tool that is frequently applied in bioarchaeology for researching human remains. Oxygen isotopic values of

Corresponding author: A. Lisowska-Gaczorek e-mail: a.lisowska-gaczorek@uksw.edu.pl animal calcified tissues are correlated with the isotopic composition of local environmental water (D'Angela and Longinelli, 1990; Daux et al., 2008; Delgado Huertas et al., 1995; Levinson et al., 1987; Longinelli, 1984; Luz et al., 1984), which in turn has a negative correlation with altitude and latitude and is positively correlated with temperature in a given location (Dansgaard, 1964; Gat, 1980, 1996; Yurtsever and Gat, 1981). The method based on the above observations makes it possible to recon- 
struct the origin of both individuals and entire human groups (Dupras and Schwarcz, 2001; Hoogewerff et al., 2001; Knudson and Torres-Rouff, 2009; White et al., 2004a, 2004b). The analysis of stable oxygen isotopes in bone tissue has also become immensely useful in tracking migration of animals and human populations (Britton et al., 2009; Henton et al., 2010; Rubenstein and Hobson, 2004; Shaw et al., 2010), migration of individuals between groups and genesis of populating certain areas (Prowse et al., 2007; White et al., 2004a, 1998, 2004b). This method likewise allows to investigate climate changes over millennia (Ayliffe et al., 1992; Bocherens et al., 1995; Daux et al., 2005; Fricke et al., 1998; Longinelli, 1984).

The main source of drinking water for historical and prehistorical human populations as well as animals coexisting with a certain group is environmental water. People used to populate areas close to lakes and rivers; they tended to take water from springs and streams. In isotope research conducted upon human and animal skeletons, a positive correlation between the isotopic composition of bone phosphates and the isotope ratio of environmental (drinking) water was observed (D'Angela and Longinelli, 1990; Daux et al., 2008; Hoppe, 2006; Levinson et al., 1987; Longinelli, 1984; Longinelli et al., 2003; Luz et al., 1984; Luz and Kolodny, 1985). In 1984, Longinelli was the first to prove that there was a significant linear relation between the average value of the isotopic composition of oxygen in rainwater and the isotopic composition of oxygen in bone phosphates (Longinelli, 1984). Also in 1984, similar analyses were conducted by Luz and collaborators (Luz et al., 1984) using laboratory rats. The results of this research have indicated that the isotope delta of oxygen in the bones and teeth of mammals reflects the origin of ingested water and food.

One of the methods of reconstructing the origins and migration paths of prehistoric peoples is the reconstruction of isotopic ranges of the environment inhabited by a given individual. To this end, information on the $\delta^{18} \mathrm{O}$ level of contemporary precipitation water in a given area is obtained, and if skeletal remains of animals are available on the archaeological site, investigators use isotopic data obtained from bone tissue carefully selected from the fauna that inhabited the area with the studied human population at the same time (Bentley and Knipper, 2005). Attempts to reconstruct past environmental conditions in the context of isotopic analysis give rise to certain issues that may affect the credibility of the interpretation of the outcomes. This is due to the fact that the average annual $\delta^{18} \mathrm{O}$ of local rainfall varies over time. Arguably, pollution is also significant in this respect. On the other hand, the conversion of the isotopic composition of oxygen in bone phosphates to $\delta^{18} \mathrm{O}$ of water generates a relatively large error margin that widens the isotopic range of the environment. Pellegrini et al. (2016) suggests that the best solution would be to avoid conversion of $\delta^{18} \mathrm{O}_{\mathrm{p}}$ to $\delta^{18} \mathrm{O}_{\mathrm{w}}$ by directly comparing the isotope delta values of bone phosphates of the analysed individuals with the $\delta^{18} \mathrm{O}_{\mathfrak{p}}$ of representatives of other populations. Hence, if skeletal remains of animals are present, it is advised to use archaeological material (animal bone phosphates) rather than contemporary material (isotopic data obtained from precipitation water) and to compare $\delta^{18} \mathrm{O}_{\mathfrak{p}}$ values instead of predicted $\delta^{18} \mathrm{O}_{\mathrm{w}}$ values (Bentley and Knipper, 2005; Pollard et al., 2011).

Apart from environmental issues, one of the most frequent doubts pertaining to the isotope research of oxygen isotopes in the context of migration is the fact that humans insert some liquids into the organisms with the isotopic composition possibly differentiated, which is determined not only by many geographical and climatic factors but also cultural (social) issues. Humans have been consuming thermally processed food ever since the Neolithic period (Kirsanow and Tuross, 2011; McGlynn, 2007). In the Middle Ages, brews, beers and alcoholic beverages were prepared in different ways, specifically by cooking, boiling or fermentation, and were frequently given to children (Brettell et al., 2012). The thermal processing of water consisted of blanching, brewing, stewing, cooking and distillation. This was the method for preparing beverages and meals based on water and solid ingredients (called stews in modern times). People also prepared brews and herbal teas with a refreshing and toning up effect on the human organism. These were made with plants such as origanum, parsley, sage, common fennel, hyssop, caraway, anise, rose, lily and tearthumb. Both adults and children were given the dried up sprouts of common chicory, mallow, common agrimony or nightshades by the medics of those times, which, in the form of brews, were used for healing symptoms of the digestive system or any lesions on the skin and in the mouth as well as headaches (Polack and Kania, 2015).

Most historical sources, including those pertaining to food-making, come from the Middle Ages. These show that the favourable method for preparing meals was to cook them slowly on low heat, which is characteristic for stewing under a lid (Brettell et al., 2012). Meals prepared in a large pot with ingredients such as herbs used as spices, meat, vegetables (including dried grain legumes) and a large amount of water were also popular in the area of Poland. Dembińska (1999) reconstructed recipes for such meals (e.g., beer soup with cheese and eggs, Pomeranian Trójniak and grud of mixed grains). Such meals had to be prepared for no less than 45 minutes (vegetable broth), on average for 2-3 hours (meat stock), "as long as it takes to walk around the field" or even "on gentle fire" for 2 days (cooked groats or cereal and game stewed with sauerkraut) (Adamson, 2004; Dembińska, 1999).

Therefore, some pieces of literature emphasise that, during the interpretation of data, one must consider the potential influence of cultural practices, such as boiling water and cooking food, on the oxygen isotope ratios in bone apatite (Brettell et al., 2012; Britton et al., 2015; Daux et al., 2008; Kendall et al., 2013; Knudson, 2009; 
Lee-Thorp, 2002; Pellegrini et al., 2016; Pollard, 2011; Prevedorou et al., 2010; Szostek et al., 2014). At the same time, it is currently often pointed out that the influence of the thermal processing of water and food on quantitative isotopic composition of bone phosphates in individuals consuming liquids and food is not accurately determined. There have been some research results published recently where the isotopic composition of some products having been subjected to thermal processing had been tested (Royer et al., 2017; Tuross et al., 2017); however, in the cited studies, the impact of isotopic changes on consumer tissues has not been studied. In some papers pertaining to weaning, their authors assume that the individuals whose remains have been subjected to isotope analyses of oxygen had consumed neither boiled water nor meals prepared by thermal processing (Britton et al., 2015; Pellegrini et al., 2016). However, our current knowledge indicates, that since ancient times, the preparation of food was associated with the use of fire. Unfortunately, there is a lack of knowledge as to what extent the consumption of boiled water and liquid foods may change the value of the isotope delta of oxygen in bone tissue.

Conducting research explaining this issue with regard to the human body tissues for obvious ethical reasons is not possible; therefore, an animal model was used in this research, which was a laboratory rat.

The primary goal of the research was to determine the influence of thermal processing of consumed water on $\delta^{18} \mathrm{O}$ in bone phosphates of rats. First, we determined the degree of fractionation on the level of tap water vs. thermally processed water. Second, we determined the influence of the thermal processing of consumed water on the isotope ratios of bone and tooth phosphates in rats.

\section{MATERIAL AND METHODS}

Due to obvious reasons, it is not possible to learn how bone tissue would change its isotopic composition in response to a factor introduced in an intra vitam experiment. Therefore, an experiment using laboratory animals has been conducted. This isotope research used the rats of the Wistar Cmd:(WI)WU strain as an animal model. It should be emphasised that rats constitute a model in a lot of research related to human metabolism, physiology and genetics. A rat is a model organism with small size, relatively quick growth, short life cycle and high fertility. A lot of data pertaining to the development and mechanism of bone and tooth mineralisation in humans comes from research based on the analysis of skeleton growth in mice and rats (Jheon et al., 2013; Smith and Warshawsky, 1975).

Animal subjects in the experiment were divided into two groups according to the type of consumed water. The first type was tap water, poured directly into drinking troughs. Water samples were obtained from a water supply network over a short period of time at the same time of the year. The water was always drawn from the same point (tap) after 5 minutes of continuous flow. The temperature of the water was controlled and each time it was $12{ }^{\circ} \mathrm{C}$. As a result, thanks to a lack of variation in air temperature and the stable temperature of the tap water, the fractionation process was limited to a minimum. Thanks to the small variability of tap water, only a few controlled supply water measurements were taken.

The second type was thermally processed water. Thermal processing of water consisted of pouring tap water into a dish with $2.5 \mathrm{~L}$ volume. The vessel was covered with a lid to $2 / 3$ of its area. Water was heated until boiling (for about 20 minutes), and then it was boiled on low heat for about 2.5 hours. Some water evaporated and left the system, and some of it condensed on a lid and went back into the container. Next, it was cooled for 15 minutes, poured into bottles (which were then sealed), and transferred to the animal quarters. Due to the fact that boiling water may cause higher variability of isotopic values of oxygen, samples of thermally processed water were obtained from each boiled batch ( 31 samples).

The experiment included 8 female rats of the Wistar Cmd:(WI)WU strain. The rat breeding was conducted in stable humidity (55\%), lighting (artificial light $60 \mathrm{~lx}$, $12 \mathrm{~h} / 12 \mathrm{~h})$, temperature $\left(22^{\circ} \mathrm{C}\right)$ and availability of feed and water ad libitum. The one and only differentiating factor was the type of consumed water. With respect to this, the group of 8 pregnant females was divided into 2 groups. The first one was a reference group that consumed tap water. The other group drank thermally processed water. The females gave birth. Young rats were kept in cages together with their mothers and breastfed for about 3 weeks. Upon weaning, young rats were raised in the same groups as their mothers, consuming only tap water or thermally processed water, depending on the type of their group. As these 22 individuals completed the 90-day period of life (3 months), they were put to sleep to collect bone and teeth samples. In total, the experiment included 30 rats. All procedures involving the animals were approved by the Ethical Committee of The Jagiellonian University in Kraków, Poland (no. 122/2011) in accordance with international standards.

The femoral diaphysis of each rat was the research material in this experiment. After cleaning any soft tissue and marrow, the femoral diaphyses were rinsed with deionized water by an ultrasonic cleaner, dried up and ground in a ball mill (Retsch MM 200) and divided into rations with a similar weight of about $0.4 \mathrm{~g}$.

The analysis of isotopic composition of oxygen was conducted for the phosphates of bone apatite. The analytical procedures of isolation of bone phosphates were conducted according to the procedure suggested by O'Neil and collaborators (1994) as described by Vennemann et al. (2002).

The isotopic composition of oxygen in the extracted phosphates was determined in the Department of Radioisotopes, Institute of Physics-CSE, Silesian University of 
Technology, Gliwice, Poland. Continuous-flow isotope ratio mass spectrometry was used. The results of isotopic analysis is presented in delta notation $\delta=\{[\mathrm{R}$ (sample)$\mathrm{R}($ standard) $] / \mathrm{R}$ (standard) $\} \times 1000$ ), where $\mathrm{R}$ refers to the measured isotopic ratio of ${ }^{18} \mathrm{O} /{ }^{16} \mathrm{O}$ (Grimes and Pellegrini, 2013). A method similar to one described by Lécuyer (2004) was used for stable oxygen isotope analysis. About $250 \mu \mathrm{g}$ of a sample of $\mathrm{Ag}_{3} \mathrm{PO}_{4}$ was wrapped in a silver capsule. Analysis for each sample was performed in triplicate. Samples were subjected to pyrolysis in a Eurovector EA3000 elemental analyser. Pyrolysis took place in a reactor filled with glassy carbon and equipped with graphite crucible heated to $1300^{\circ} \mathrm{C}$. During pyrolysis, carbon monoxide was formed, which was then taken by helium flow to a gas chromatograph where it was separated from residual atmospheric nitrogen. A sample of $\mathrm{CO}$ was introduced into the IsoPrime isotope ratio mass spectrometer through an open-split interface. Before each sample, the monitoring $\mathrm{CO}$ gas (Linde, 4.7 grade) was analysed. In addition to the three NIST-120C (Lécuyer et al., 1996; Stephan, 2000) standard samples analysed in the beginning of each batch of about 20 samples (60 sub-samples), one NIST-120C standard sample was analysed. $\delta^{18} \mathrm{O}=-21.7 \%$ Vienna Standard Mean Ocean Water (VSMOW) was used as a reference for the NIST-120C standard (Lécuyer et al., 1996). Pre-treatment of the NIST-120C samples was the same as for all the apatite samples. Measurement uncertainties for the samples were estimated as the standard deviation of the NIST-120C measurement within the same batch.

\section{RESULTS}

This paper encompasses an attempt to examine how the isotopic deltas are being changed during long-term boiling ( $\mathrm{ca} .2 .5$ hours) and also to check how the isotopic composition of oxygen changes in apatite phosphates in bone tissue upon consumption of water prepared in such a way.

For this purpose, the first step included analysis of obtained values of isotope ratios for tap water and thermally processed water.

Detailed data of the analysis are given in Supplementary Material. Due to disproportion in the number of samples of thermally processed water and tap water (31 $v s$. 4), the evaluation of differences in isotopic composition was conducted with application of the MannWhitney $U$ test. This test indicated statistically significant difference between the variables $(\mathrm{W}=62.0$; $p=0.00142963 ; p<0.05)$. The isotopic composition of oxygen in thermally processed water was higher by about $6.1 \%$ (between medians) than the isotopic value of tap water (Fig. 1).

The composition of stable oxygen isotopes in tap water and thermally processed water was used to calculate the values of isotopic deltas of bone phosphates, with the application of an equation developed for laboratory rats by Luz and Kolodny (1985) (Fig. 2). This was for the purpose of ensuring a possibility to compare isotopic results obtained for rats participating in the experiment with the values of potable water, and, subsequently, a possibility to extrapolate the obtained research results further to the human population, using regression equations developed for determination of the relation between apatite phosphates and the isotopic delta of potable water.

This was followed by an analysis of the variability of the isotopic composition of oxygen in the bone tissue of rats that drank tap water and rats that consumed thermally processed water. The analysis of the results of the isotopic analysis of bone phosphates began with checking if there was a significant difference in the isotopic composition of apatites in the bones and teeth. It turned out that there were no statistically significant differences between the analysed tissues (Mann-Whitney test: $p=0.5736$ ). Similar results concerning the lack of differences between the bone and tooth tissues of rats were obtained by Luz and Kolodny (1985). This is probably due to the continuous mineralisation of constantly growing teeth (incisors), whose remodelling rate might be similar to that of bones. Due to the lack of significant differences between the analysed tissues, further analyses were based on combined bone and teeth results.

In order to verify whether there were any differences between young (weaned) individuals and their adult mothers, isotope ratios were compared with the use of Mann-Whitney's nonparametric test. It turned out that there were no statistical differences between females and

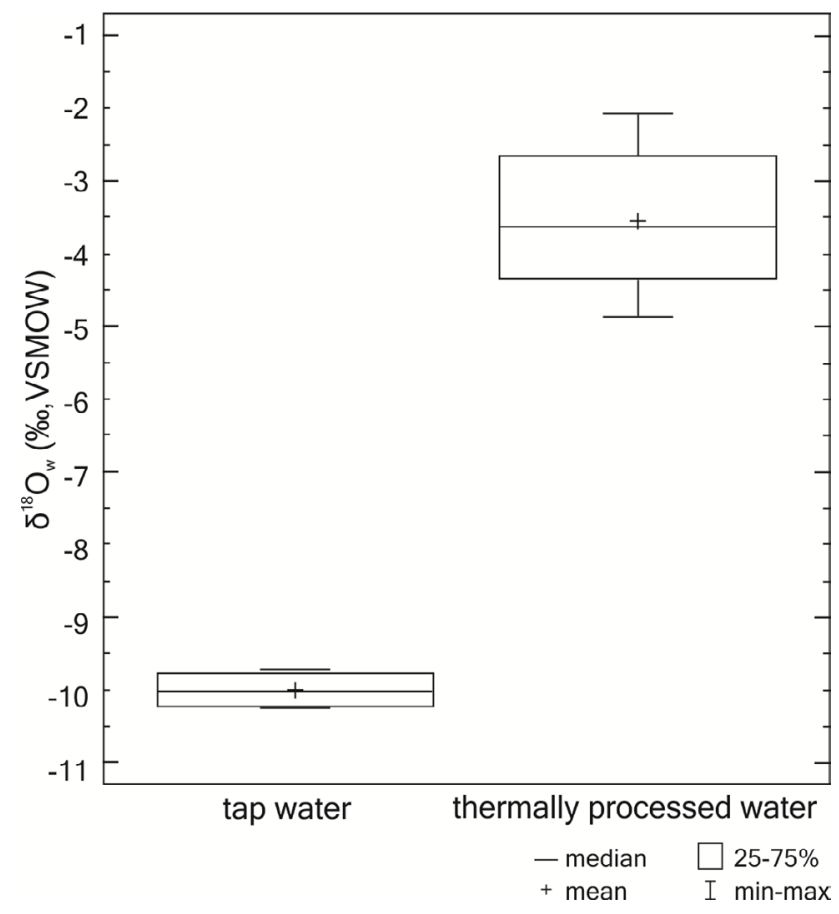

Fig. 1. The values of oxygen isotopic delta of tap water and thermally processed water with the measurement errors. 


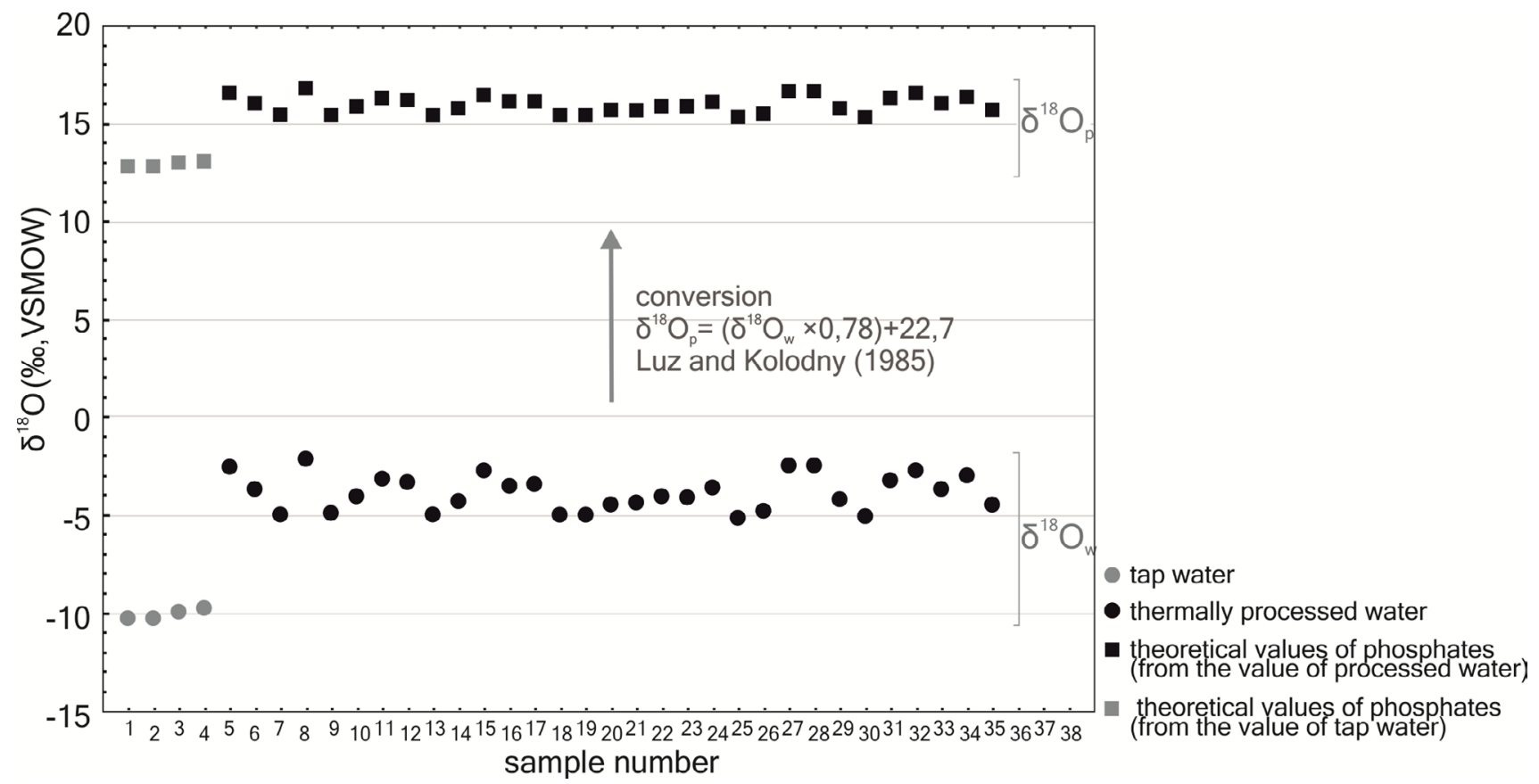

Fig. 2. The isotopic composition of water given to laboratory rats, recalculated to values of the isotopic composition of apatite phosphates in specimens potentially consuming water with a certain composition.

their offspring ( $\mathrm{W}=320, \mathrm{p}=0.08)$. Hence, adult females and their weaned offspring were combined into a single group for further analyses.

The next stage consisted of verifying whether there were any statistically significant differences between the isotopic composition of water calculated into phosphates and the isotopic delta of apatite phosphates in rat bones. The results for water were calculated based on a regression equation proposed by Luz and Kolodny (1985), which is the only equation dedicated to rats available in the literature. In the case of tap water, there were no statistically significant differences between the median $\delta^{18} \mathrm{O}$ of tap water calculated to phosphates and the $\delta^{18} \mathrm{O}$ of phosphates in the bones of rats drinking tap water $(\mathrm{W}=19.0, \mathrm{p}=0.082)$. However, there was a significant difference in the case of boiled water. The median $\delta^{18} \mathrm{O}$ of thermally processed water converted to phosphates was lower than the median $\delta^{18} \mathrm{O}$ of phosphates in rats drinking thermally processed water $(\mathrm{W}=180.0, \mathrm{p}=0.000)$. It was noted that the variability observed in the bone apatites of the studied animals overlapped with the variability of water calculated to bone phosphates within its lower variability ranges.

In order to verify the hypothesis about a lack of significant differences between the groups of rats drinking boiled and tap water, a nonparametric Mann-Whitney test was conducted, which revealed that the difference between the medians was statistically significant $(\mathrm{W}=13.0$; $\mathrm{p}=0.000$ ) and amounted to nearly $4.0 \%$. This means that the rats consumed boiled water were characterised by an approximately $29 \%$ higher $\delta^{18} \mathrm{O}$ value compared to the rats consuming tap water (Fig. 3 ).

It needs to be emphasised that the fractionation observed during water evaporation in the course of the experiment resulted in an increase of the water's oxygen isotopic delta by $6.1 \%$.

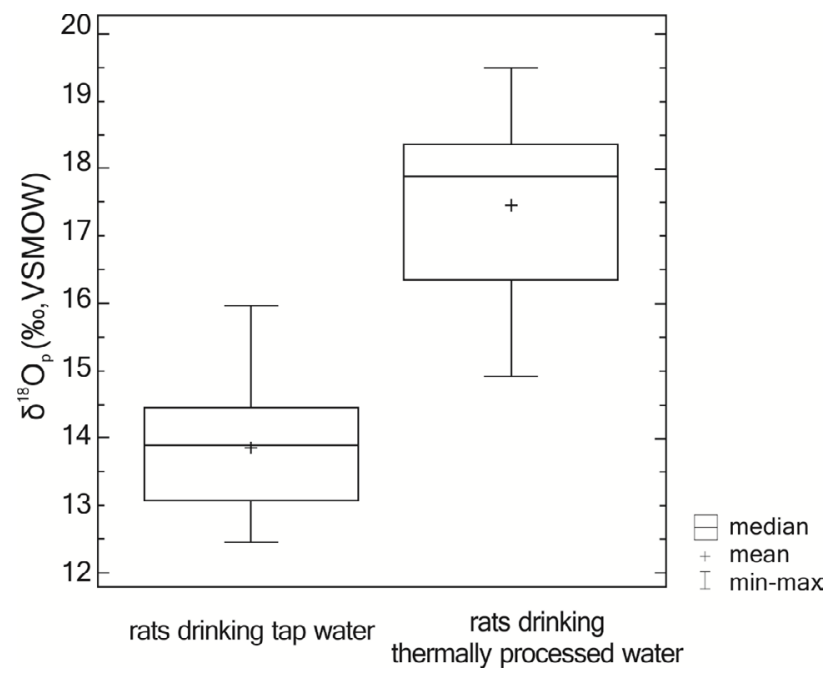

Fig. 3. The difference in the values of isotopic delta of bone phosphates in animals consuming two different types of water. 


\section{DISCUSSION}

It is not possible to generalise and develop a universal plan for the issue of preparing beverages and meals in human history. Cooking, whether short and intensive or slow, is inevitably connected to evaporation and therefore to isotopic fractionation. During cooking, the water temperature increases, thus intensifying the molecule movement. Heavy isotopes $\left({ }^{18} \mathrm{O}\right)$ have larger bonding energy, lower diffusion speed and move slower than lighter molecules $\left({ }^{16} \mathrm{O}\right)$. Therefore, the frequency of collision between the ${ }^{18} \mathrm{O}$ isotopes is lower. Such differences in physio-chemical properties of isotopes translate to general reactivity of chemical compounds consisting of such isotopes. In the process of boiling water, relatively more lighter isotopes $\left({ }^{16} \mathrm{O}\right)$ are eliminated, together with steam, under the influence of temperature, which makes the water in the container isotopically heavier.

During their research, Brettel and collaborators (2012) conducted a similar experiment where water was cooked in pans for 10 minutes and 180 minutes, respectively. In the mentioned studies, the time of cooking/evaporation was a significant factor affecting the results of the isotopic composition of water and meals subjected to thermal processing. The change of isotopic delta values in the aforementioned experiment was $+0.4 \%$ and $+26.2 \%$, respectively, as compared to the starting level of $\delta^{18} \mathrm{O}_{\mathrm{w}}$. The result obtained in this research was significantly different from the results obtained in the Brettel paper (2012), largely due to methodological reasons. One might assume that the containers used to cook water or liquid food in the past were not entirely uncovered but (depending on the historical period, existence and development of pottery techniques) could have been entirely closed, as in stewing and cooking in leather containers shaped like a conical pot (narrower at the top) or at least partially covered. In each of the above cases, water evaporation was being limited. Steam escaped into the atmosphere to a large extent; however, some water condensed on the container walls or the lid and returned to the solution. In the experiment herein, the pot filled with water was cov- ered $2 / 3$ with a lid; therefore, some water escaped the system, and some of it condensed on the lid and the container. As may be concluded from the comparison of both experiments, slow cooking on low heat and partially covering the container limited the intensity of evaporation and therefore the degree of isotopic fractionation of oxygen in the course of thermal processing of water.

It should be noted that the variability of isotopic values in water that has been cooked for about 2.5 hours is quite high (Fig. 1). This results from the fact that a change of isotopic delta values of oxygen in the course of cooking, particularly long-term cooking, may vary. It is widely known that changes of atmospheric pressure affect the boiling point of water (Atkins, 2001). Consequently, despite the fact that the water volume, the covered area and the amount of energy supplied to the system were similar each time, the differences of atmospheric pressure entailed changes in evaporation intensity (Atkins, 2001). This translated to the occurrence of variability in the fractionation degree at the level of tap water-boiled water and the final isotopic ratios of water that was previously thermally processed.

The existence of such fluctuations did not, however, significantly affect the research issue being considered. It would be illogical and unimaginable to assume that the preparation of meals by human populations occurred under the same pressures and temperatures over the centuries. A significant result of the conducted analyses is, therefore, the observation of change of isotopic composition of oxygen in thermally processed water, consisting of an increase of its value by $+6.1 \%$, which may constitute a reference point for further analyses.

Isotopic fractionation of oxygen in the course of thermal processing of food and its effect in the form of change of isotopic delta were already observed (Brettell et al., 2012; Daux et al., 2008; Tuross et al., 2017). As with cooked water, the aforementioned papers also indicated an increase of isotopic values of oxygen against time and temperature (Table 1).

In the paper by Daux and collaborators (2008), the isotopic analysis encompassed the ingredients of a meal (vegetables, meat and fish), the water in which the food

Table 1. The influence of thermal processing of food on isotopic ratios of oxygen in cooked food according to different authors.

\begin{tabular}{|c|c|c|c|c|}
\hline Paper & Material & $\begin{array}{l}\text { Cooking time } \\
\text { (min.) }\end{array}$ & $\begin{array}{c}\text { Temperature } \\
\left({ }^{\circ} \mathrm{C}\right)\end{array}$ & Isotopic effect of cooking process \\
\hline \multirow{3}{*}{ Daux et al., 2008} & Food (vegetables) water vs initial water & 20 & $\min .100$ & $+6.2 \%$ \\
\hline & Food (meat) water vs initial water & 20 & $\min .100$ & $\begin{array}{c}+2.2 \% \text { (chicken) } \\
+2.8 \% \text { (beef) } \\
+3.7 \% \text { (mackerel) }\end{array}$ \\
\hline & Food (rice, lentils) water vs initial water & 20 & $\min .100$ & $+2.6 \%$ \\
\hline \multirow{2}{*}{ Brettel et al., 2012} & Vegetables and meat & 60 & $\min .100$ & $+4.0 \%$ \\
\hline & Vegetables and meat & 180 & $\min .100$ & $+10.1 \%$ \\
\hline \multirow{3}{*}{ Tuross et al., 2017} & Sweet potato & 300 & 125 & $+3.0 \%$ \\
\hline & Sweet potato & 300 & 150 & $+6.0 \%$ \\
\hline & Meat & 270 & 125 & $+1.1 \%$ \\
\hline
\end{tabular}


was cooked, and the water from the aforementioned products upon 20 minutes of cooking. The result of that research was the conclusion that water contained in meat cooked for a short time and the water in which such meat was cooked did not differ significantly in terms of isotopic composition. A slightly larger difference in isotopic delta was observed for the water isolated from vegetables in comparison to the water in which such vegetables were cooked. It was also noted that the isotopic value of cooked vegetables altered by less per mille than the water such vegetables were submerged in, and the less hydrated vegetable was, the higher the change of isotopic value.

Bone phosphates enter the state of isotopic balance with the body's water very fast. The isotopic composition of body water is correlated to the composition of $\delta^{18} \mathrm{O}$ of drinking water (Levinson et al., 1987; Longinelli, 1984; Luz et al., 1984). The isotopic ratios of apatites in bone tissue are strongly correlated with the isotopic delta of oxygen in water being consumed by a living organism (eg. Longinelli, 1984; Luz et al., 1984).

It just so happens, however, there are differences between the environmental variability of $\delta^{18} \mathrm{O}_{\mathrm{w}}$ and $\delta^{18} \mathrm{O}_{\mathrm{p}}$, because in some geographic regions, the values of oxygen isotopes within phosphates do not correspond to those observed in the environmental water. This may be a sign that there is some other factor than a physiological or environmental one that plays an important role in shaping the relationship at the level: local environmental water skeleton (Pellegrini et al., 2016). In isotopic research aiming to determine origin or migration, it is indicated that there is a requirement to evaluate the potential influence of food-making practices on the values of isotopic deltas of apatite phosphates to enable a critical and reliable assessment of what can actually be determined upon the analyses employing such a methodology (Brettell et al., 2012; Britton et al., 2015; Camin et al., 2008; Kennedy et al., 2011; Lee-Thorp, 2002; Pellegrini et al., 2016; Pollard, 2011; Prevedorou et al., 2010; Szostek et al., 2014).

It needs to be emphasised that, within the premises of the experiment, the only factor differentiating the two groups of rats was the type of water they consumed. Other factors which might have affected the conditions of the experiment, including air temperature and humidity, were controlled on a regular basis.

\section{Paleoanthropological applications}

The source literature emphasises that, in the case of analysing the mobility of a group of humans with the application of oxygen isotopes, there is a need to evaluate a potential effect of culinary practices on the values of isotopic ratios in bone phosphates (Brettell et al., 2012; Britton et al., 2015; Camin et al., 2008; Daux et al., 2008; Lee-Thorp, 2002; Pollard, 2011; Prevedorou et al., 2010; Szostek et al., 2014). This is relevant in order to conduct a critical and thorough evaluation of the origin or migration paths of the individuals in whom the isotope values of bone apatites exceed the upper limit of the isotopic range of a given environment (Brettell et al., 2012; Britton et al., 2015; Pellegrini et al., 2016; Prevedorou et al., 2010). Environmental isotope data of a given microregion may come from the analysis of local water, animals living close to humans (domesticated, homestead, less mobile species) or comparative isotopic data from other, previously studied human populations. The use of each of these elements is associated with difficulties. Comparative data from other human groups are rarely available and appropriate (the same time and region of being). The values of isotopic composition of local environmental water show variability over time, and under the influence of cooking or storage (eg. Brettel et al., 2012). Conversions also cause a significant error (Pollard et al., 2011). On the other hand, animals, by differences in body size or physiology, may also display variations in the isotope delta of oxygen in bones (Gregoricka, 2013). Therefore, the isotopic oxygen values used to evaluate migration of our ancestors must be interpreted with caution. It is also important to gain knowledge about how to extend the interpretation possibilities and reduce the potential error.

As has already been mentioned, the range of the isotopic variability of an environment is obtained by analysing contemporary water in a given area or the use of isotopic calculators (Daux et al., 2008; Gregoricka et al., 2017; Gregoricka and Sheridan, 2017; Hamre and Daux, 2016; Müldner et al., 2011; Osipowicz et al., 2017; Parks, 2009) and/or analysing the remains of another human groups or animals who inhabited that area with the analysed groups of humans in different periods of time (Oleszczak et al., 2018; Parks, 2009; Shaw et al., 2010; Stepańczak, 2012).

In order to determine the range of isotopic variability of a given living environment of a prehistoric population, we use the observation of the existing relationship between the isotopic composition of bone phosphates and environmental (drinking) water (Daux et al., 2008; Levinson et al., 1987; Longinelli, 1984; Luz et al., 1984). Due to the fact that contemporary surface water does not always constitute a good reflection of prehistoric isotopic environmental conditions (climate change, hydrogeochemical change and pollution), scientists apply available regression equations (Daux et al., 2008; Levinson et al., 1987; Longinelli, 1984; Luz et al., 1984) along with analyses of fauna from the examined archaeological sites (Roberts et al., 2013; Shaw et al., 2010; Szostek et al., 2014). As a result, the isotopic values of apatite phosphates obtained from the analysis of skeletal remains are converted to the isotopic values of environmental water, which in turn allows us to relate the results of bone analyses to the environmental background created in this manner (Pellegrini et al., 2016). It needs to be noted that the conversion aimed at predicting $\delta^{18} \mathrm{O}_{\mathrm{w}}$ values based on the determined $\delta^{18} \mathrm{O}_{\mathrm{p}}$ values may be a source of significant statistical error (Pollard et al., 2011). Taking the 
above into consideration, in order to limit errors resulting from the interpretation of the results to a minimum, the isotopic composition of the rats' bone tissue and of the water consumed by the animals was closely controlled during this experiment.

The available regression equations, developed based on the natural variability of water in the natural environment (Daux et al., 2008; Levinson et al., 1987; Longinelli, 1984; Luz et al., 1984), show how isotopic values of oxygen in the bones correspond to a specific proportion of stable isotopes of oxygen in consumed water. Given the above, it is worth finding out how boiling water translates into the isotopic composition of tissues. Could thermal processing of food potentially cause certain deviation from the dependencies observed in nature in the context of the body's reaction to the introduction of boiled liquids?

Fig. 4 shows the results of the variability of isotopes of oxygen in rat bone phosphates. This data relates to the regression lines showing the relationship between $\delta^{18} \mathrm{O}_{\mathrm{w}}$ and $\delta^{18} \mathrm{O}_{\mathrm{p}}$ for different species of the order Rodentia. It turns out that $\delta^{18} \mathrm{O}_{\mathrm{p}}$ results for rat apatites obtained in this analysis are positioned higher than the regression line determined for this species by Luz and Kolodny (1985). However, based on the comparison of $\delta^{18} \mathrm{O}_{\mathfrak{p}}$ values determined in the bones with those calculated from water samples, statistically significant differences between the medians (Mann-Whitney test) were obtained only in the case of boiled water ( $\mathrm{W}=688 ; \mathrm{p}=, 000)$. We can only assume that this fact may be caused by the physiological effects of ingesting and assimilating "isotope-heavy" water into tissues, or (even more likely) it could mean that the curve of the regression line determined by Luz and Kolodny (1985) for rats needs to be tweaked. The need for verifying the regression line is justified by the fact that the results obtained in this analysis fall within the broad variation of the curves of regression lines determined for other species of the order Rodentia (Fig. 4). This observation requires further investigation and perhaps even a new delineation of the regression line for rats based on more $\delta^{18} \mathrm{O}_{\mathfrak{p}}$ analyses for these animals with a differentiated level of $\delta^{18} \mathrm{O}$ of drinking water.

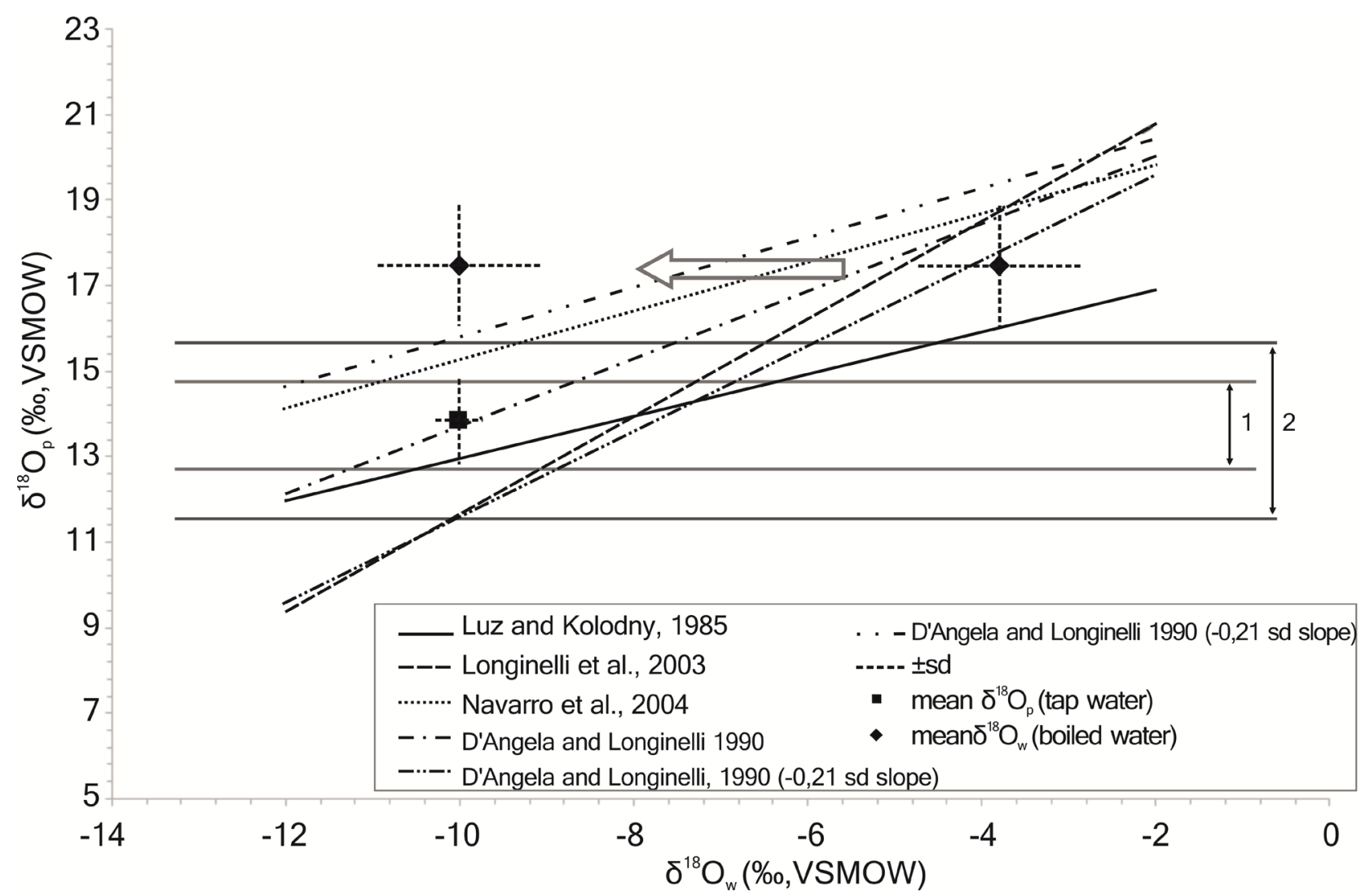

Fig. 4. $\delta^{18} \mathrm{O}_{p}$ mean values $( \pm s d)$ of bone samples from rats drinking tap water (square) and thermally processed water (diamond) plotted versus the $\delta^{18} \mathrm{O}$ average of tap water $(-10.011 \%)$ and thermally processed water $(-3.7894 \%)$ respectively. Horizontal lines determine the range of $\delta^{18} \mathrm{O}$ variability in the environmental water from the area of Kraków. Scope no. 1 was determined based on the results obtained for rats drinking tap water \pm 1 sd. Scope no. 2 was determined as the minimum and maximum values determined on the basis of the presented regression lines. The results obtained for rats drinking boiled water were shifted to the same level as the results for rats drinking tap water to better visualize the relationship to the compared groups and reference to ranges showing the local environmental level. 
When extrapolating the results obtained from the animal model described above to the interpretations of results for prehistoric human populations, similar trends are likely to be expected. What is more, the enormous biocultural diversity of the human race translates into differentiation of corresponding mathematical models for our species (Daux et al., 2008; Levinson et al., 1987; Longinelli, 1984; Luz et al., 1984; Pollard et al., 2011) (Fig. 5). Given the above, how can the results of this study be used in bioarchaeological analyses involving attempts at separating autochthonous and allochthonous individuals considering potential culinary practices and their effects on isotopic changes observed in the skeleton?

As it has been mentioned above, in order to analyse the mobility of human groups and determine potential immigrants, the results obtained from the human osteological material need to be related to and confronted with the isotopic environmental background characteristics of the studied area.

The analysed individuals exhibited values below the lower limit of the isotopic variability of the environmental background are potential allochthons, whereas those whose results exceeded the upper limit of the background did not necessarily so. This results from the fact that there is a range of both physiological and biocultural factors that may increase isotope values in the body, including culinary practices (Brettell et al., 2012; Daux et al.,
2008). This is why the interpretation of this type of phenomenon is approached with great caution in bioarchaeological analyses.

The analyses described in this paper have shown that the range of $\delta^{18} \mathrm{O}_{\mathfrak{p}}$ variability (between Q1-Q2 quantiles) in rats drinking tap water was $13.07-14.44 \%$, which may be deemed as the environmental background for the isotopic ratio of water for this area. On the other hand, when considering the $\delta^{18} \mathrm{O}_{\mathrm{p}}$ level of the environmental background according to the regression line for rodents, we obtain a range of 11.61-15.81\% (assuming $\delta^{18} \mathrm{O}_{\mathrm{w}}=-10 \%$ ), which confirms the previous statement that the variability of the $\delta^{18} \mathrm{O}$ level in environmental water is higher than the variability of $\delta^{18} \mathrm{O}$ in bone phosphates (Fig. 4). Therefore, when confronting these ranges with the results obtained for organisms drinking boiled water, we may presume that this may be a result of consuming boiled water rather than having a different origin if the level of $\delta^{18} \mathrm{O}_{p}$ is higher within the limits of $4 \%$ (if animals are considered to be the environmental background) or $2.6 \%$ (if water is considered to be the environmental background).

Based on the result obtained for rats, it could be surmised that those individuals who exceeded the upper $\delta^{18} \mathrm{O}$ limit of the environmental range by up to $3-4 \%$ may be considered representatives of the studied group, provided the group consumed thermally processed food from the biocultural point of view. Raising the upper value of the

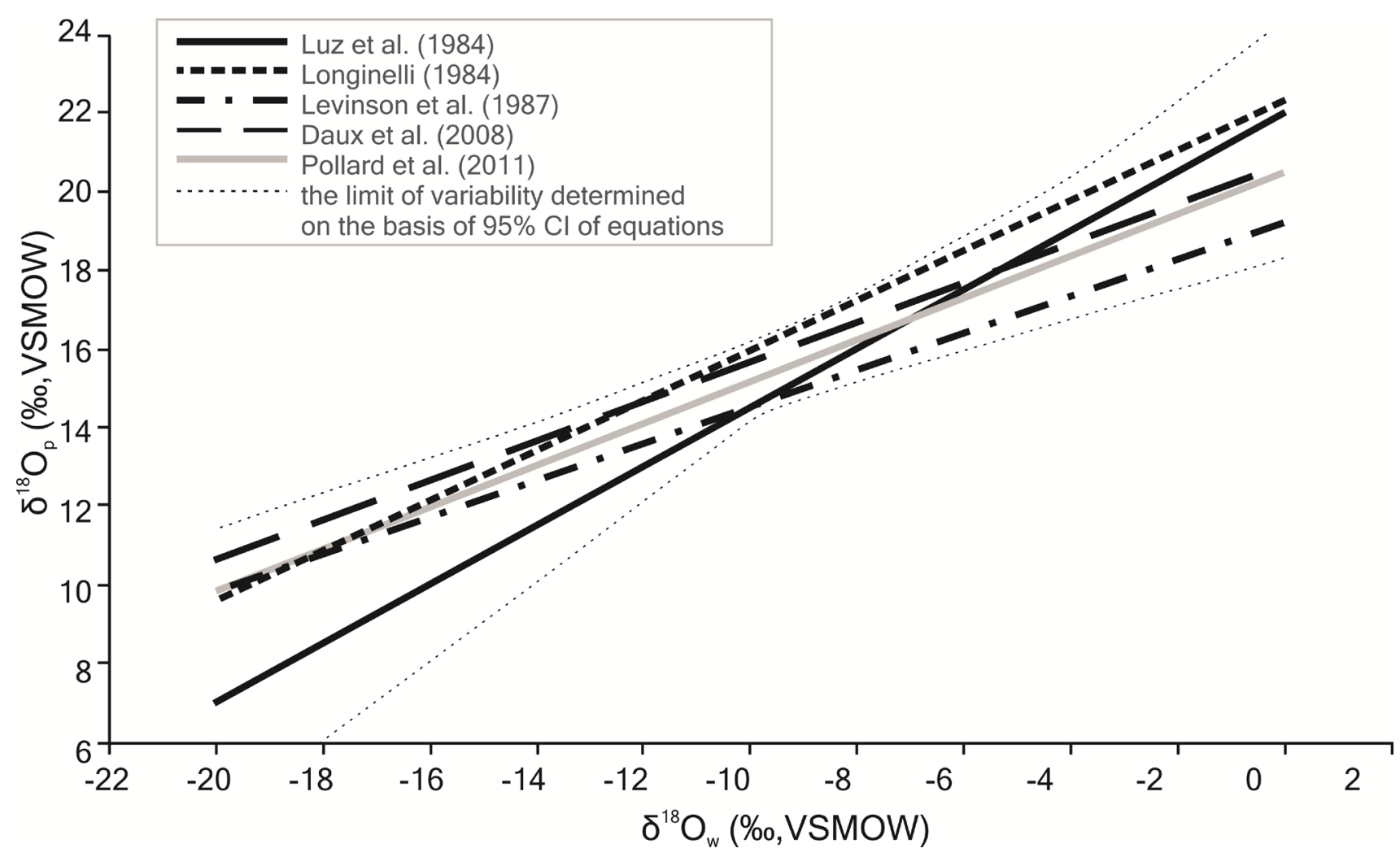

Fig. 5. Variability of oxygen isotopic composition based on the relationship between $\delta^{18} \mathrm{O}_{p}$ and $\delta^{18} \mathrm{O}_{w}$ in human studies. 
environmental background estimated based on the analyses of fauna or environmental water by the value obtained on the basis of this model seems to be justifiable for most of the populations, as the factor connected to processing food, which is a unique and almost immanent feature of our species, is known to have occurred at least since Neolithic biocultural transformations (Kirsanow and Tuross, 2011; McGlyn, 2007).

\section{CONCLUSIONS}

The analyses described in this paper have contributed to expanding knowledge about the influence of the thermal processing of consumed water on the isotopic composition of apatite phosphates.

The experiment conducted on the laboratory rat has yielded the following results:

1) Raising the values of the isotopic composition of water by $c a .6 .1 \%$ during prolonged boiling for $2.5 \mathrm{~h}$ resulted in raised $\delta^{18} \mathrm{O}$ values in the apatite phosphates of rats drinking water by approximately $4 \%$. This means that, in rats drinking thermally processed water, values of the isotopic composition of oxygen in apatites are approximately $29 \%$ higher on average.

2) The isotopic values of tap water calculated to phosphates fall within the broad range of variability defined by regression equations for rodents (D'Angela and Longinelli, 1990; Luz and Kolodny, 1985; Navarro et al., 2004). However, the variability of the isotopic composition of oxygen in apatite phosphates of rats drinking both tap water and boiled water overlaps with the values predicted based on the equation from Luz and Kolodny (1985) only in the lower part of the range.

3) Consuming thermally processed water (potentially boiled meal) significantly raises the isotopic level in a rat's body by approximately 3-4 per mille (29\%). It may be assumed that regular consumption of isotopeheavy drinks and foods by humans may cause a similar effect. Exceeding the upper limit of the isotopic range of environmental variability by just a few per mille may mean that the individual belonged to the studied local population, assuming that the drinks and food consumed by the group were thermally processed.

\section{SUPPLEMENTARY MATERIAL}

Supplementary material, containing the results of isotopic analyses of oxygen in tap water and thermally processed water samples are available online at http://dx.doi.org/10.2478/geochr-2020-0001.

\section{ACKNOWLEDGMENTS}

This research was supported by the National Science Centre (Poland) [grant number 2014/15/N/NZ8/00351].
We would like to thank the staff from The Department of Neuroanatomy Jagiellonian University, especially Zuzanna Setkowicz and Małgorzata Kaczyńska for donating the animal tissues used in this study.

\section{REFERENCES}

Adamson MW, 2004. Food in Medieval Times. Food Through History. Greenwood Press: London.

Atkins PW, 2001. Chemia fizyczna. PWN.

Ayliffe LK, Lister AM and Chivas AR, 1992. The preservation of glacial-interglacial climatic signatures in the oxygen isotopes of elephant skeletal phosphate. Palaeogeography, Palaeoclimatology, Palaeoecology 99(3-4): 179-191, DOI 10.1016/00310182(92)90014-V.

Bentley RA and Knipper C, 2005. Geographical patterns in biologically available strontium, carbon and oxygen isotope signatures in prehistoric southwest Germany. Archaeometry 47(3): 629-644, DOI 10.1111/j.1475-4754.2005.00223.x.

Bocherens H, Fogel ML, Tuross N and Zeder M, 1995. Trophic Structure and Climatic Information From Isotopic Signatures in Pleistocene Cave Fauna of Southern England. Journal of Archaeological Science 22(2): $327-340, \quad$ DOI 10.1006/jasc. 1995.0035.

Brettell R, Montgomery J and Evans J, 2012. Brewing and stewing: The effect of culturally mediated behaviour on the oxygen isotope composition of ingested fluids and the implications for human provenance studies. Journal of Analytical Atomic Spectrometry 27(5): 778-785, DOI 10.1039/c2ja10335d.

Britton K, Fuller BT, Tütken T, Mays S and Richards MP, 2015. Oxygen isotope analysis of human bone phosphate evidences weaning age in archaeological populations. American Journal of Physical Anthropology 157(2): 226-241, DOI 10.1002/ajpa.22704.

Britton K, Grimes V, Dau J and Richards MP, 2009. Reconstructing faunal migrations using intra-tooth sampling and strontium and oxygen isotope analyses: a case study of modern caribou (Rangifer tarandus granti). Journal of Archaeological Science 36(5): 11631172, DOI 10.1016/j.jas.2009.01.003.

Camin F, Perini M, Colombari G, Bontempo L and Versini G, 2008. Influence of dietary composition on the carbon, nitrogen, oxygen and hydrogen stable isotope ratios of milk. Rapid Communications in Mass Spectrometry. John Wiley \& Sons, Ltd. 22(11): 16901696, DOI 10.1002/rcm.3506.

D'Angela D and Longinelli A, 1990. Oxygen isotopes in living mammal's bone phosphate: Further results. Chemical Geology: Isotope Geoscience Section 86(1): 75-82, DOI 10.1016/01689622(90)90007-Y.

Dansgaard W, 1964. Stable isotopes in precipitation. Tellus 16(4): 436468, DOI 10.3402/tellusa.v16i4.8993.

Daux V, Lécuyer C, Adam F, Martineau F and Vimeux F, 2005. Oxygen isotope composition of human teeth and the record of climate changes in France (Lorraine) during the last 1700 years. Climatic Change 70(3): 445-464, DOI 10.1007/s10584-005-5385-6.

Daux V, Lécuyer C, Héran MA, Amiot R, Simon L, Fourel F, Martineau F, Lynnerup N, Reychler H and Escarguel G, 2008. Oxygen isotope fractionation between human phosphate and water revisited. Journal of Human Evolution 55(6): 1138-1147, DOI 10.1016/j.jhevol.2008.06.006.

Delgado Huertas A, Iacumin P, Stenni B, Sánchez Chillón B and Longinelli A, 1995. Oxygen isotope variations of phosphate in mammalian bone and tooth enamel. Geochimica et Cosmochimica Acta 59(20): 4299-4305, DOI 10.1016/0016-7037(95)00286-9.

Dembińska M, 1999. Food and Drink in Medieval Poland Rediscovering a Cuisine of the Past. University of Pennsylvania Press: Philadelphia.

Dupras TL and Schwarcz HP, 2001. Strangers in a strange land: Stable isotope evidence for human migration in the Dakhleh Oasis, Egypt. Journal of Archaeological Science 28(11): 1199-1208, DOI 10.1006/jasc.2001.0640. 
Fricke HC, Clyde WC and O'Neil JR, 1998. Intra-tooth variations in $\delta 180$ (PO4) of mammalian tooth enamel as a record of seasonal variations in continental climate variables. Geochimica et Cosmochimica Acta 62(11): 1839-1850, DOI 10.1016/S00167037(98)00114-8.

Gat JR, 1980. Handbook of environmental isotope geochemistry. Volume 1, The terrestrial environment, A. In: Fritz P and Fontes JC (eds) Handbook of environmental isotope geochemistry. Volume 1, The terrestrial environment, A. Elsevier : Amsterdam, Oxford, New York, 21-48.

Gat JR, 1996. Oxygen and Hydrogen Isotopes in the Hydrologic Cycle. Annual Review of Earth and Planettary Sciences 24:225-262. DOI 10.1146/annurev.earth.24.1.225.

Gregoricka LA, 2013. Geographic origins and dietary transitions during the bronze age in the oman peninsula. American Journal of Physical Anthropology 152(3): 353-369, DOI 10.1002/ajpa.22360.

Gregoricka LA, Scott AB, Betsinger TK and Polcyn M, 2017. Deviant burials and social identity in a postmedieval Polish cemetery: An analysis of stable oxygen and carbon isotopes from the "vampires" of Drawsko. American Journal of Physical Anthropology 163(4): 741-758, DOI 10.1002/ajpa.23244.

Gregoricka LA and Sheridan SG, 2017. Continuity or conquest? A multi-isotope approach to investigating identity in the Early Iron Age of the Southern Levant. American Journal of Physical Anthropology 162(1): 73-89, DOI 10.1002/ajpa.23086.

Grimes V and Pellegrini M, 2013. A comparison of pretreatment methods for the analysis of phosphate oxygen isotope ratios in bioapatite. Rapid Communications in Mass Spectrometry 27(3): 375-390, DOI 10.1002/rcm.6463.

Hamre SS and Daux V, 2016. Stable oxygen isotope evidence for mobility in medieval and post-medieval Trondheim, Norway. Journal of Archaeological Science: Reports. The Authors 8(July): 416-425, DOI 10.1016/j.jasrep.2016.06.046.

Henton E, Meier-Augenstein W and Kemp HF, 2010. The use of oxygen isotopes in sheep molars to investigate past herding practices at the neolithic settlement of çatalhöyük, central anatolia. Archaeometry 52(3): $\quad 429-449, \quad$ DOI $\quad 10.1111 / \mathrm{j} .1475-$ 4754.2009.00492.x.

Hoogewerff J, Papesch W, Kralik M, Berner M, Vroon P, Miesbauer H, Gaber O, Künzel KH and Kleinjans J, 2001. The last domicile of the Iceman from Hauslabjoch: A geochemical approach using Sr, $\mathrm{C}$ and $\mathrm{O}$ isotopes and trace element signatures. Journal of Archaeological Science 28(9): 983-989, DOI 10.1006/jasc.2001.0659.

Hoppe KA, 2006. Correlation between the oxygen isotope ratio of North American bison teeth and local waters: Implication for paleoclimatic reconstructions. Earth and Planetary Science Letters. $\quad$ Elsevier 244(1-2): 408-417, DOI 10.1016/J.EPSL.2006.01.062.

Jheon AH, Seidel K, Biehs B and Klein OD, 2013. From molecules to mastication: The development and evolution of teeth. Wiley Interdisciplinary Reviews: Developmental Biology 2(2): 165-182, DOI 10.1002/wdev.63.

Kendall EJ, Montgomery J, Evans JA, Stantis C and Mueller V, 2013. Mobility, mortality, and the middle ages: Identification of migrant individuals in a 14th century black death cemetery population. American Journal of Physical Anthropology 150(2): 210-222, DOI 10.1002/ajpa.22194.

Kennedy CD, Bowen GJ and Ehleringer JR, 2011. Temporal variation of oxygen isotope ratios $(\delta 180)$ in drinking water: Implications for specifying location of origin with human scalp hair. Forensic Science International. Elsevier Ireland Ltd 208(1-3): 156-166, DOI 10.1016/j.forsciint.2010.11.021

Kirsanow K and Tuross N, 2011. Oxygen and hydrogen isotopes in rodent tissues: Impact of diet, water and ontogeny. Palaeogeography, Palaeoclimatology, Palaeoecology. Elsevier B.V. 310(1-2): 9-16, DOI 10.1016/j.palaeo.2011.03.022.

Knudson KJ, 2009. Oxygen isotope analysis in a land of environmental extremes: The complexities of isotopic work in the Andes. International Journal of Osteoarchaeology 19(2): 171-191, DOI 10.1002/oa.1042.
Knudson KJ and Torres-Rouff C, 2009. Investigating cultural heterogeneity in San Pedro de Atacama, northern Chile, through biogeochemistry and bioarchaeology. American Journal of Physical Anthropology 138(4): 473-485, DOI 10.1002/ajpa.20965.

Lécuyer C, 2004. Oxygen Isotope Analysis of Phosphate. Handbook of Stable Isotope Analytical Techniques. Elsevier, 482-496, DOI 10.1016/B978-044451114-0/50024-7.

Lécuyer C, Grandjean P, Paris F, Robardet M and Robineau D, 1996 Deciphering "temperature" and "salinity" from biogenic phosphates: the $\delta 180$ of coexisting fishes and mammals of the Middle Miocene sea of western France. Palaeogeography, Palaeoclimatology, Palaeoecology. Elsevier 126(1-2): 61-74, DOI 10.1016/S0031-0182(96)00070-3.

Lee-Thorp J, 2002. Two decades of progress towards understanding fossilization processes and isotopic signals in calcified tissue minerals. Archaeometry 44(3): 435-446, DOI 10.1111/14754754.t01-1-00076.

Levinson AA, Luz B and Kolodny Y, 1987. Variations in oxygen isotopic compositions of human teeth and urinary stones. Applied Geochemistry 2(4): 367-371, DOI 10.1016/0883-2927(87)90021-7.

Longinelli A, 1984. Oxygen isotopes in mammal bone phosphate: A new tool for paleohydrological and paleoclimatological research? Geochimica et Cosmochimica Acta 48(2): 385-390, DOI 10.1016/0016-7037(84)90259-X.

Longinelli A, Iacumin P, Davanzo S and Nikolaev V, 2003. Modern reindeer and mice: Revised phosphate-water isotope equations. Earth and Planetary Science Letters 214(3-4): 491-498, DOI 10.1016/S0012-821X(03)00395-9.

Luz B and Kolodny Y, 1985. Oxygen isotope variations in phosphate of biogenic apatites, IV. Mammal teeth and bones. Earth and Planetary Science Letters 75(1): 29-36, DOI 10.1016/0012821X(85)90047-0.

Luz B, Kolodny Y and Horowitz M, 1984. Fractionation of oxygen isotopes between mammalian bone-phosphate and environmental drinking water. Geochimica et Cosmochimica Acta 48(8): 16891693, DOI 10.1016/0016-7037(84)90338-7.

McGlyn G, 2007. Using 13C-, 15N- and $18 \mathrm{O}$ stable isotope analysis of human bone tissue to identify transhumance, high altitude habitation and reconstruct palaeodiet for the early medieval Alpine population at Volders, Austria. Ludwig-Maximilians-Universität München

Müldner G, Chenery C and Eckardt H, 2011. The "Headless Romans": Multi-isotope investigations of an unusual burial ground from Roman Britain. Journal of Archaeological Science. Elsevier Ltd 38(2): 280-290, DOI 10.1016/j.jas.2010.09.003.

Navarro N, Lécuyer C, Montuire S, Langlois C and Martineau F, 2004. Oxygen isotope compositions of phosphate from arvicoline teeth and Quaternary climatic changes, Gigny, French Jura. Quaternary Research 62(2): 172-182, DOI 10.1016/j.yqres.2004.06.001.

O’Neil JR, Roe LJ, Reinhard E and Blake RE, 1994. A rapid and precise method of oxygen isotope analysis of biogenic phosphate. Israel Journal of Earth Sciences (I): 203-212.

Oleszczak Ł, Borodovskiy AP, Lisowska-Gaczorek A, Pawlyta J, Kozieł S, Tur SS, Cienkosz-Stepańczak B and Szostek K, 2018. The Origin of Culturally Diversified Individuals Buried in the Early Iron Age Barrow Cemetery at Chultukov Log-1 (Upper Altai) in Light of the Analysis of Stable Oxygen Isotopes. Collegium antropologicum 42(1): 27-37.

Osipowicz G, Witas H, Lisowska-Gaczorek A, Reitsema L, Szostek K, Płoszaj T, Kuriga J, Makowiecki D, Jędrychowska-Dańska K and Cienkosz-Stepańczak B, 2017. Origin of the ornamented bâton percé from the Gołebiewo site 47 as a trigger of discussion on long-distance exchange among Early Mesolithic communities of Central Poland and Northern Europe. PLoS ONE 12(10), DOI 10.1371/journal.pone. 0184560 .

Parks CL, 2009. Oxygen Isotope Analysis of Human Bone and Tooth Enamel: Implications for Forensic Investigations. Thesis. San Marcos. Texas.

Pellegrini M, Pouncett J, Jay M, Pearson MP and Richards MP, 2016. Tooth enamel oxygen "isoscapes" show a high degree of human 
mobility in prehistoric Britain. Scientific Reports. Nature Publishing Group 6: 1-9, DOI 10.1038/srep34986.

Polack G and Kania K, 2015. The middle ages unlocked: a guide to life in medieval England, 1050-1300. Stroud: Amberley.

Pollard AM, 2011. Isotopes and impact: A cautionary tale. Antiquity 85(328): 631-638, DOI 10.1017/S0003598X00068034.

Pollard AM, Pellegrini M and Lee-Thorp JA, 2011. Technical note: Some observations on the conversion of dental enamel $\delta 180$ p values to $\delta 18 \mathrm{Ow}$ to determine human mobility. American Journal of Physical Anthropology 145(3): 499-504, DOI 10.1002/ajpa.21524.

Prevedorou E, Bonilla MD, Romero A, Buikstra JE, Paz de Miguel Ibáñez M and Knudson KJ, 2010. Residential Mobility and Dental Decoration in Early Medieval Spain: Results from the Eighth Century Site of Plaza del Castillo , Pamplona. Dental Anthropology 23(2): 42-52.

Prowse TL, Schwarcz HP, Garnsey P, Knyf M, Macchiarelli R and Bondioli L, 2007. Isotopic evidence for age-related immigration to imperial Rome. American Journal of Physical Anthropology 132(4): 510-519, DOI 10.1002/ajpa.20541.

Roberts CA, Millard AR, Nowell GM, Gröcke DR, MacPherson CG, Pearson DG and Evans DH, 2013. Isotopic tracing of the impact of mobility on infectious disease: The origin of people with treponematosis buried in Hull, England, in the late medieval period. American Journal of Physical Anthropology 150(2): 273285, DOI 10.1002/ajpa.22203.

Royer A, Daux V, Fourel F and Lécuyer C, 2017. Carbon, nitrogen and oxygen isotope fractionation during food cooking: Implications for the interpretation of the fossil human record. American Journal of Physical Anthropology 163(4): 759-771, DOI 10.1002/ajpa.23246.

Rubenstein DR and Hobson KA, 2004. From birds to butterflies: Animal movement patterns and stable isotopes. Trends in Ecology and Evolution 19(5): 256-263, DOI 10.1016/j.tree.2004.03.017.

Shaw B, Buckley H, Summerhayes G, Anson D, Garling S, Valentin F, Mandui H, Stirling C and Reid M, 2010. Migration and mobility at the Late Lapita site of Reber-Rakival (SAC), Watom Island using isotope and trace element analysis: a new insight into Lapita interaction in the Bismarck Archipelago. Journal of Archaeological Science. Elsevier Ltd 37(3): 605-613, DOI 10.1016/j.jas.2009.10.025.

Smith CE and Warshawsky H, 1975. Cellular renewal in the enamel organ and the odontoblast layer of the rat incisor as followed by radioautography using $3 \mathrm{H}$-thymidine. The Anatomical Record 183(4): 523-561, DOI 10.1002/ar.1091830405.
Stepańczak B, 2012. Zastosowanie stabilnych izotopów tlenu w badaniu mieszkańców przedlokacyjnego Krakowa. (The use of stable oxygen isotopes in the study of Kraków's pre-lokation residents) Thesis. Kraków. (in Polish).

Stephan E, 2000. Oxygen Isotope Analysis of Animal Bone Phosphate: Method Refinement, Influence of Consolidants, and Reconstruction of Palaeotemperatures for Holocene Sites. Journal of Archaeological Science. Academic Press 27(6): 523-535, DOI 10.1006/JASC.1999.0480.

Szostek K, Haduch E, Stepańczak B, Kruk J, Szczepanek A, Pawlyta J, Gła;b $\mathrm{H}$ and Milisauskas S, 2014. Isotopic composition and identification of the origins of individuals buried in a Neolithic collective grave at Bronocice (southern Poland). HOMO- Journal of Comparative Human Biology 65(2): 115-130, DOI 10.1016/j.jchb.2013.11.001.

Tuross N, Reynard LM, Harvey E, Coppa A and McCormick M, 2017. Human skeletal development and feeding behavior: the impact on oxygen isotopes. Archaeological and Anthropological Sciences. Archaeological and Anthropological Sciences 9(7): 1453-1459, DOI 10.1007/s12520-017-0486-5.

Vennemann TW, Fricke HC, Blake RE, O'Neil JR and Colman A, 2002. Oxygen isotope analysis of phosphates: a comparison of techniques for analysis of Ag3PO4. Chemical Geology. Elsevier 185(3-4): 321-336, DOI 10.1016/S0009-2541(01)00413-2.

White C, Longstaffe FJ and Law KR, 2004a. Exploring the effects of environment, physiology and diet on oxygen isotope ratios in ancient Nubian bones and teeth. Journal of Archaeological Science 31(8): 233-250, DOI 10.1016/j.jas.2003.08.007.

White CD, Spence MW, Longstaffe FJ and Law KR, 2004b. Demography and ethnic continuity in the Tlailotlacan enclave of Teotihuacan: The evidence from stable oxygen isotopes. Journal of Anthropological Archaeology 23(4): 385-403, DOI 10.1016/j.jaa.2004.08.002.

White CD, Spence MW, Stuart-Williams HLQ and Schwarcz HP, 1998. Oxygen isotopes and the identification of geographical origins: the Valley of Oaxaca versus the Valley of Mexico. Journal of Archaeological Science 25(7): 643-655, DOI 10.1006/jasc.1997.0259.

Yurtsever Y and Gat JR, 1981. Atmospheric waters. In: Gat J.R and Gonfiantini R, eds., Stable Isotope Hydrology. Deuterium and Oxygen-18 in the Water Cycle. International Atomic Energy Agency, Vienna, 210: 103-142. 